\title{
Skirting or Courting Controversy? Chinese FDI in Latin American Extractive Industries
}

\author{
Adriana Erthal Abdenur
}

\begin{abstract}
China has become a key player in the development sector in Latin America and the Caribbean (LAC), not only due to trade but also because of the growing scope and visibility of its foreign direct investments (FDI). However, Chinese investments in the region are far from homogeneous, not only oscillating over time and space, but also varying across modes of incorporation into LAC economies. In the extractive industries, Chinese actors rely on a wide gamut of strategies to open up markets and to help ensure access to oil and minerals. This chapter breaks down the concept of FDI into three umbrella categories-greenfield projects, mergers and acquisitions, and joint ventures - to analyse how Chinese capital enters LAC extractive sectors. The chapter argues that, faced with a relatively unfamiliar landscape and new sources of uncertainty, Chinese companies tend to 'test the water' through mergers and acquisitions, as well as joint ventures, before delving into greenfield activities like direct mining or drilling. This cautious approach signals a degree of institutional learning on the part of Chinese stakeholders, as well as the desire to avoid charges of neo-colonialism, imposed dependency, and lax adherence to formal regulations.
\end{abstract}

\section{Introduction}

In January 2015, during the first meeting between China and the Community of Latin American and Caribbean States (CELAC), held in Beijing, President Xi Jinping made headlines when he announced that Chinese investments in the region would reach USD 250 billion within a decade (China, 2015). Considering that the stock of investments at that point had been estimated at

* The author wishes to thank the Bolsa de Produtividade programme of Brazil's National Council of Technological and Scientific Development (Conselho Nacional de Desenvolvimento Científico e Tecnológico, CNPq) for supporting this research.

(C) ADRIANA ERTHAL ABDENUR, 2017 | DOI 10.1163/9789004351677_010

This is an open access chapter distributed under the terms of the CC-BY-NC License 
USD 99 billion, Xi's statement appeared to foreshadow a dramatic surge in Chinese foreign direct investments (FDI) in Latin America and the Caribbean (LAC) (The Economist, 2015). The cooperation agreements that followedmany focusing on oil, gas and mining — provoked new discussions within LAC countries about the relationship between extractive industries, sustainable development and dependence on external actors, including South-South cooperation providers such as the BRICs countries (Brazil, Russia, India, China and South Africa), but China in particular.

Interpretations of the surge in Chinese investments in LAC have ranged from charges of Chinese neo-colonialism to rose-tinted views of China as an economic saviour during times of crisis. One critic called the proposed expansion in investments by China 'a poisoned chalice', noting that some of the large infrastructure projects being planned for the region may leave a massive environmental footprint and exacerbate social exclusion (Salazar, 2015). A us-based analysis has added to the alarm by warning that China has been 'gobbling up' minerals and 'locking up natural resource supplies, gaining preferential access to available output, extending control over the world's extractive industries' (Kotschwar et al., 2012). At the opposite end of the spectrum, Xi's announcement has been hailed by others as a silver bullet solution to the region's economic woes, especially given the gap in development financing and the significant economic slowdown that some of LAC's key economies, including Brazil and Argentina, have been experiencing since 2015.

However, sweeping statements about China's role in LAC tend to overlook the highly variable forms and effects of China's investments in the region-not to mention the fact that many, if not most, major projects announced never see the light of day. ${ }^{1}$ Among the initiatives that do get implemented, Chinese investments have been concentrated heavily in the region's major commodities exporters, especially Venezuela and Brazil, and extractive nodes like Chile and Peru. This concentration is also reflected in Chinese loans to Latin American countries (Table 9.1).

Nevertheless, investment levels only tell part of the story; different modes of insertion also shape China's role in fomenting (or preventing) sustainable development in LAC, and Chinese firms adopt different strategies depending on the local context. How have Chinese investments in the Latin American extractive sector changed over the past decade? This chapter analyses three categories of Chinese investments: mergers and acquisitions, joint ventures, and greenfield projects. The main argument is that, faced with a variety of institutional barriers to entry and new sources of uncertainty, Chinese

1 Interviews with Brazilian economists in Rio de Janeiro and São Paulo, May 2016. 


\begin{tabular}{lcc}
\hline & Number of loans & Amount (in USD billions) \\
\hline Argentina & 8 & $15 \cdot 3$ \\
Bahamas & 2 & 0.99 \\
Barbados & 1 & 0.17 \\
Bolivia & 6 & 1.6 \\
Brazil & 8 & 21.8 \\
Costa Rica & 1 & 0.39 \\
Ecuador & 11 & 15.2 \\
Guyana & 1 & 0.1 \\
Jamaica & 9 & 1.5 \\
Mexico & 1 & 1.0 \\
Peru & 1 & 0.05 \\
Trinidad & 2 & 2.68 \\
Venezuela & 17 & 65.0 \\
TOTAL & 68 & $125 \cdot 78$ \\
\hline
\end{tabular}

SOURCE: CHINA-LATIN AMERICA FINANCE DATABASE (WASHINGTON, D.C.: THE INTERAMERICAN DIALOGUE), HTTP://WWW.THEDIALOGUE.ORG/MAP_LIST/ (ACCESSED ON 13 JANUARY 2016).

companies tend to 'test the water' through mergers and acquisitions, as well as joint ventures, before delving into direct mining or drilling. This cautious approach - driven not only by profit-seeking but also by a more immediate desire to skirt political controversy-sometimes makes China less salient in Latin American public debates as compared to debates in other regions. When Chinese firms do invest in greenfield projects, especially large-scale initiatives with considerable environmental footprints and social impact, they are subject to broader contestation, especially on the part of local civil society groups, and risk becoming the subject of negative coverage by Latin American as well as external media outlets.

The chapter is structured in the following manner. The first section provides an overview of the political economy of Latin American extractive industries, especially in light of the significant changes in the range of actors involved in the sector and the intensifying debate over how mineral extraction relates to sustainable development. Next, the chapter compares different modes 
of Chinese investment in Latin American extractive industries, drawing on examples from around the region. The conclusion examines some of the key implications of these modes of insertion for the broader study of the role of China in Latin America's sustainable development and notes a few directions for future research.

\section{$2 \quad$ FDI and Sustainable Development}

The role of extractive industries in promoting economic growth and development has long been debated, including within the Latin American context. During the Cold War, modernisation theorists saw the expanding extraction of oil, gas and other minerals as part of an intermediary development stage in Latin American economies' progression from predominantly agrarian, traditional societies to modern industrial economies-particularly when extraction created savings that could be invested in infrastructure (Germani, 1969). In contrast, dependency theorists-including the Latin American structuralistssaw natural resources as being siphoned away from the periphery to a core of wealthy countries, further enriching the latter at the expense of the former (see Prebisch, 1950; Furtado, 1974; Cardoso and Faletto, 1979). In this second perspective, Latin American extractive industries were viewed as a central nexus in the creation and maintenance of the region's ties of dependent development in relation to the centres of the world economy. The Marxist variant of dependency theory included the idea of a 'new dependency', in which the internal and external relations of peripheral states, including those in LAC, contributed towards the reproduction of power and wealth asymmetries, both within and across countries (Santos, 1970).

The debate between modernisation and dependency theorists peaked in the 196os and early 7os before running out of steam - partly due to the newly industrialised countries (NICs) in East Asia, whose rise seemed to contradict the idea of a rigidly hierarchical and inflexible world economy. However, in the new millennium, the links between the extractive industries and socioeconomic development in LAC have once again become the subject of sharp debates, primarily because of China's rapid economic expansion and its quest to secure reliable sources of oil, gas and other minerals abroad. The concept of dependency, which had long gone out of fashion in development and policy circles, resurfaced as LAC experienced another commodities boom, with some economies specialising more narrowly in extractive industries and especially after China overtook the United States as the top destination for these commodities exports. From 2009 to 2013, extractive products comprised four out 
of the top five LAC exports to China (the exception being soybeans and other oilseeds) (Ray and Gallagher, 2015).

Although these exports helped to increase Latin American government revenues, some critics began sounding alarms over the growing focus on a few commodities and heavy reliance on a single or few trade partners. Gallagher and Porzecanski (2010), for instance, expressed concern about the volatility of commodity prices and its long-term impact on LAC economies. Yet the concern that commerce with China could lead to excessive specialisation in commodities by LAC countries has not borne out; for Brazil, for instance, while commodities exports have risen, so have other, higher-value-added sectors. At the same time, some observers called attention to the particular dynamics surrounding this 'second wave' of dependency, including the intensification of globalisation and growing concerns over sustainable development, which were not nearly as pronounced when the original debate on dependency took place. Another novel aspect concerns the salience of the concept of the resource curse, in reference to situations in which rents from extraction are easily captured, poorly distributed among the population, and/or siphoned abroad, exacerbating social inequality and undermining democratisation. Some analysts have argued that, rather than succumbing to the resource curse, LAC has in fact experienced a 'resource blessing' with windfalls from the extractive industries generating positive externalities for a broader swath of the population and helping to boost democratisation (Dunning, 2008). On the other hand, within the debate on the 'Dutch Disease,' recent research has shown that Chinese exports of manufactured goods have had both direct and indirect effects that contribute towards deindustrialisation in some of the region's countries, although the impact seems to be highly variable according to country and sector (see, for instance, Jenkins, 2015).

Another difference between the original dependency debates and the current scenario in LAC is that, at a global level, the extractive industries have undergone 'tectonic' shifts over the past fifteen years. Until the turn of the millennium, the sector grew more or less along with global GDP, but demand for these commodities then began outpacing global GDP. The primary driver of this surge was the expansion of the Chinese economy, with its heavy reliance on infrastructure and manufacturing and its inadequate national supply of key minerals, including iron ore (needed for steel production). By 2015, an estimated 40-6o per cent of the world's mineral production ended up in China (some of it to be exported again in manufactured form) (Lichtenstein, 2013). One of the results of this growing demand was a steep rise in the prices of those commodities; from 2000 to 2012 alone, for example, the price of iron ore increased by around 1,00o per cent. 
LAC's wealth in minerals and ore reserves was one of the major reasons China began to deepen its ties to states within the region, starting in the 1990s. This rapprochement had political and strategic dimensions, but it manifested itself most visibly in the economic arena. China quickly overtook the United States and European countries as the top trade partner of many LAC countries. With respect to FDI in LAC, by 2010 China had become LAC's third largest investor, second only to the us and the Netherlands. However, there are clear patterns across modes of investment and the role that oil and other mineral extraction plays in each. Among greenfield projects, the vast majority of major Chinese investments are not in the extractive sector but rather in manufacturing, agriculture, logistics, communications, and finance and real estate. In contrast, Chinese mergers and acquisitions in LAC during the same period concentrated heavily in oil and the extractive sector (Ray and Gallagher, 2015). These patterns suggest a much greater reluctance and/or lesser capacity of Chinese companies to engage in greenfield projects in the extractive sector.

The Chinese government has played a significant role in opening up new opportunities and facilitating new trade and investment deals for Chinese companies; in the smaller economies of Central America and the Caribbean, most large deals are struck between governments. Elsewhere, Chinese companies-whether state-owned enterprises (soEs) or private firmsincreasingly favour joint ventures and direct takeovers of private companies, yet the Chinese state is often involved in umbrella negotiations. This means that, in addition to seeking profits, companies try to align with the priorities established by the Chinese government, for instance as laid out in the Five-Year Plans, white papers, and other planning and policy instruments, especially as they relate to energy security. Spurred on by the government's Go Out Policy, which has encouraged Chinese companies to seek investment opportunities abroad as a way of channelling some of the country's large foreign exchange reserves, of securing natural resource supplies (especially where upstream investments are concerned) and of diversifying away from us dollar transactions, soes in oil, gas and mining have looked for mineral producers with considerable production potential, and these include LAC countries. However, China's enthusiasm for LAC minerals has also elicited some scepticism; González-Vicente (2011), for instance, worries that China's miningrelated activities abroad tend to reproduce some of the negative domestic context, such as lax environmental standards and poor compliance, predatory profit-making, corruption, and lack of democracy. It remains unclear, however, how and to what extent different modes of investment may impact local governance in LAC countries along these dimensions, if at all, and especially in comparison to other sources of FDI. 


\section{Modes of Insertion of Chinese FDI in Latin America and the Caribbean}

Although Chinese companies began investing abroad heavily around the turn of the millennium and these flows increased steadily over the next decade, the 2008 onset of the global economic crisis provided new impetus for Chinese FDI. By 2014, Chinese outbound investment was set to eclipse inbound investment - what a World Economic Forum report has referred to as 'the new chapter of Chinese-outward mercantilism', aimed at securing a higher rate of return on foreign assets (Aizenman, 2015). This surge in outbound investment began taking a new form, one that hinted at how influential the Chinese government remains in shaping outward investment flows: FDI bundled together with bilateral trade and credit (including renminbi swap lines), applied especially to emerging economies and commodity exporting countries, including some with a recent history of default, such as Argentina and Venezuela. In some instances, such as Venezuela, much Chinese lending (estimated at around USD $5^{\circ}$ billion over the past decade) is secured by 'in kind' long-run payments in the form of oil supplies.

In pursuing investment opportunities abroad, Chinese firms (much like transnational corporations based in other countries) adopt a variety of FDI strategies, in the sense of acquiring a controlling ownership in a business enterprise in another country. From the perspective of host countries, these flows are not guaranteed to produce positive development outcomes; policy makers and social scientists alike have long debated the capacity of FDI in oil, gas and minerals to foster economic growth and socio-economic development. Its proponents defend the practice, arguing that FDI in extractive industries promotes growth and productivity within the host country, for instance by stimulating domestic investment and total investment in the country (adding to the capital stock) and by producing externalities in the form of technology transfer and spillovers that enhance efficiency (see, for instance, Carkovic and Levine, 2002). Critics, on the other hand, note that gains are far from automatic-for instance, FDI is far more likely to have a positive effect in more open economies and those that already have developed financial systems; others note that FDI can entail significant risks for local actors, including the destruction of local capabilities and inadequate compensation for extractive activities (see Te Velde, 2006 for a broad discussion).

Moreover, it is not only the amount of FDI but also the form that it takes that shapes the impact of such flows. FDI strategies vary widely, but can be grouped into three broad categories: mergers and acquisitions, joint ventures, and greenfield investments. In mergers and acquisitions, companies purchase 
existing operations, in part or in whole, in the host country. This can entail an equity stake in either an established (typically large) locally operating company, or an up-and-coming firm, sometimes with a view to establishing a 'special relationship' with a particular firm (Moran, 2010). Chinese companies have engaged in mergers and acquisitions abroad since the 1990s, but recently have turned en masse to this strategy as a way of entering overseas markets during economic slowdown and falling currency.

In joint ventures, a foreign-based company establishes a formal partnership with another firm through contracts designed to create a business unit; the participating firms both contribute towards costs and share the profits. This mode can entail loans-either granted in return for a purchase agreement to service the loan, or to finance an up-and-coming producer in return for a purchase agreement to service the loan. According to Li (2009), many Chinese companies view joint ventures as opportunities to generate a series of advantages, including knowledge flows, technology transfer, and increases in innovation capabilities (Li, 2009). For Latin American actors, joint ventures may be viewed as necessary for making specific projects feasible from cost and risk-management perspectives, since many of these projects are too costly for a single company to take on alone. This is particularly the case for multi-billion dollar oil and gas projects, especially in deep water, where risk-sharing is seen as desirable. In less liberalised countries, joint ventures are also a way of ensuring a level of local political control over inbound investments.

Finally, greenfield investments involve a foreign-based company setting up its own installations and operations in the host country, whether through development 'from scratch' or the expansion of existing sites (brownfield projects). In the extractive sector, this strategy is often pursued in places with untapped mineral resources, and/or where local companies lack the necessary capital to undertake major exploration and development. Greenfield projects are generally considered to incur a higher level of 'liabilities of foreignness'social and economic costs incurred when operating in foreign markets-when compared to mergers and acquisitions and joint ventures, because the first of these can entail significant capital expenditure on new mining projects and tend to involve higher uncertainty and risk (Huang and Zhu, 2016).

The decision to pursue each of these modes of investment (or a combination thereof) is determined by factors not only within the investing firm itself, but also within the host country, such as the regulatory framework, corporate tax rates, pre-existing competitors or collaborators, and labour costs-all of which affect the relative cost of each mode (Raff et al., 2004). In turn, each type of investment entails a particular mix of regulatory frameworks, social relations, and institutional partnerships with local stakeholders. 
Over the past decade, the extractive industries have become dramatically more important for several LAC countries, not only for economic reasons, but also due to the social and political issues that can emerge from exploration for, and the production and refining of, minerals. Given the growing global demand for these commodities, many governments within LAC have begun viewing mineral exploration as a promising driver of growth and development. Even for left-leaning regimes, the revenue from extractive industries became essential to the poverty reduction strategies implemented over the past decade and even began featuring prominently in political campaigns (in Brazil, for instance, Dilma Rousseff promised to channel windfalls from future pre-salt oil exploration to finance public education). Yet, even as productive investments in the sector have made many LAC governments eager to attract more Chinese FDI, they have also made more local stakeholders sensitive to the potentially negative political, socio-economic and environmental impacts of those investments. Some governments have encountered difficulties in balancing the purported benefits of this extractive boom (not only Chinese FDI, but also from Northern actors such as the United States) with its costs, such as environmental degradation, community displacement and enhanced socio-economic inequalities (see, for example, Irwin and Gallagher, 2013).

The ambiguous relationship between the extractive industries and socioeconomic development contributes to a highly variable landscape in LAC. Some governments, eager for additional revenue sources, work to create a stable investment climate (World Bank, 2015). They also compete in the hope that FDI will bring in more technology and capital, for instance by placing greater or new limits on taxes and royalties that apply to private companies, or by reducing legal and regulatory constraints on the establishment and operations of extractive industries. At the same time, transnational corporations often condition their investments on the loosening of environmental controls, the reduction of price controls, and the freedom to control foreign exchange earnings and to remit profits overseas. Other governments, fearing disruptive investments and the siphoning of wealth abroad, have doubled down on barriers to entry or expansion (World Bank et al., 2013).

Policies are crucial in shaping the impact of FDI on sustainable development, here defined as positive socio-economic change based on growth that not only minimises environmental damage but that is also as socially inclusive as possible (Sachs, 2014). Over the past decade, international organisations such as the World Bank and the Inter-American Development Bank, along with civil society entities, have contributed to a 'sustainable mining' discourse around LAC's extractive sector, calling for greater safeguards and standards for mitigating environmental degradation and social conflicts (World Bank, 2016). 
Despite these efforts, some analysts believe that, overall, LAC governments are generally moving away from the implementation of environmental and social protections in the extractive sector.

Within LAC, a country's general approach to FDI in the extractive sector depends in part on its government's economic orientation. Over the past decade, governments with relatively heterodox preferences emerged in parts of LAC, including in Bolivia, Ecuador, Argentina (during the Kirchner governments, 2003-15), Brazil (2003-16), Uruguay, Peru and Venezuela. Domestically, these governments focused heavily on poverty alleviation and inequality reduction, while abroad they sought greater policy autonomy from the global powers, particularly the United States. There are important differences between the previous wave of developmentalism and the current landscape. For instance, whereas during the import substitution industrialisation (ISI) period LAC states worked to protect domestic firms against foreign competition, using tariffs, price controls and FDI regulation, in the contemporary context there is near consensus within the region regarding the need to foster innovation and technological progress as part of a broader strategy of insertion into global markets.

As a result, there has been some continuity in relation to the Washington Consensus era in that even the more heterodox among LAC governments tend to view multinational companies as venues for international insertion, and to look upon FDI as a source of capital, technology and employment. This view helps explain why these governments have actively sought out $\mathrm{FDI}$, for instance by creating high-profile government agencies dedicated to the attraction of inbound FDI or working with international organisations to streamline their investment promotion strategies, both bilaterally and through multilateral arrangements like the Pacific Alliance and Asia-Pacific Economic Cooperation (APEC) (see, for example, OECD, 2015). At the same time, LAC governments have paid greater attention not only to the size of investment flows but also to the 'quality' of these inflows, for instance the extent to which investments are accompanied by technology transfer and/or positively affect the trade balance.

Among LAC states labelled the 'New Left,' the governments of Bolivia, Ecuador and Venezuela - all of which have actively promoted the idea of a break with the past and the arrival of 'socialism of the 21st century' - have tried to renegotiate contracts with transnational corporations in the extractive sector. More orthodox governments in LAC have also sought out FDI, but have tried to create more incentives for investments through a greater reliance on reducing the operating costs of firms and limiting the role of the state (Trubek et al., 2014). Thus, despite the emergence of some broad trends, the region's political landscape cannot be reduced to a clear-cut orthodox/heterodox dichotomy. 
Although Chinese investments in LAC have become more visible in development debates in the region, it is important to note that China is far from the only source of FDI in LAC; in fact, Chinese investments pale in comparison to those from the Netherlands, which remains the region's biggest source of FDI (ECLAC, 2015). However, since 2012 a sharp increase in announced Chinese investments has prompted broader debates about the scope of China's impact on the political economy of LAC, as well as questions about whether Chinese investors operate differently as compared to Northern players.

Throughout LAC, Chinese companies have pursued a broad range of investment strategies, especially in soy, oil and iron (Ellis, 2009). Variation exists within single countries. For instance, in a survey of Chinese companies investing in Brazil from 2007 to June 2012, Frischtak et al. $(2013,13)$ found that 57 per cent of all Chinese investments were in greenfield projects (a total of 34 projects), 35 per cent were in mergers and acquisitions (21 projects) and 8 per cent were in joint ventures ( 5 projects). In addition, individual Chinese companies - many of which have accumulated three or four decades of experience investing abroad - seldom specialise in one mode of investment, instead tailoring their approach in accordance with local barriers and incentives to entry and their own familiarity (or lack thereof) with the dynamics of the sector concerned.

In LAC's extractive sectors, Chinese investment strategies have also been influenced by companies' previous experiences in other regions, especially in parts of Africa where Chinese investments in mining and other extractive activities have a longer history (Gonzalez-Vicente, 2011). The oil and gas SOE Sinopec, for instance, has encountered a variety of reactions to its upstream and downstream investments in African states, ranging from a warm welcome to increased local tensions and resistance. Sinopec has also learned to compete with other companies and has even used Chinese government loans to outcompete Western-based international organisations such as the International Monetary Fund (IMF), as in the case of Angolan oil block leases (Alden and Davies, 2006). Thus, by the time Chinese companies enter LAC markets, they have undergone some degree of institutional learning, albeit in contexts that are politically, economically and institutionally quite different from those encountered in LAC.

\subsection{Greenfield Projects: From Infrastructure to Opencast Mining}

China's greenfield project investments in LAC countries range widely in how directly they are related to the actual exploration for, and production of, oil, gas 
and minerals - from building roads to facilitate access and transport, to opencast mining. At one end of the spectrum, Chinese companies have invested in infrastructure meant to facilitate these activities, especially in countries where the legal, bureaucratic or financial barriers to entry are relatively high, as in the case of Brazil. For instance, although Sinopec now invests in Brazil through multiple modes of insertion, around a decade ago it began entering the Brazilian market by participating in major gas-related infrastructure projects. In its first greenfield project in the country, Sinopec was contracted by Brazil's stateaffiliated oil company, Petrobras, to build two stretches of the Southeast Northeast Interconnection Gas Pipeline, known as GASEne. Despite the size of the pipeline-meant to create a common gas market in Brazil and facilitate gas imports through the state of Bahia - the project's environmental and social impact has not been the object of widespread contestation, either in domestic or international debates. ${ }^{2}$

Investment in extraction-related infrastructure like the GASENE project holds two advantages from the perspective of Chinese firms. First, improving infrastructure can help create new extractive opportunities and ensure gains in the mid to long term, especially when production potential is high. Second, this mode of entry can allow Chinese firms to become better acquainted with local conditions and practices before engaging more directly and committing more of their non-capital resources to extractive activities. The infrastructure route is thus regarded as a way to 'test the water': a somewhat discrete way for Chinese firms (by now, wary of negative publicity) to become involved in projects that are viewed by local stakeholders as being relatively risk-free in terms of environmental and social impacts. The GASENE project illustrates this logic: the initiative acquired greater strategic significance for both Sinopec and the Chinese government because, starting in 2007, discoveries of major reserves of oil and gas within the pre-salt layers off the Brazilian coast generated high expectations about the country's long-term potential as a supplier of both commodities. Over the next few years, as will be explored later in this chapter, Brazil and China signed a series of official cooperation agreements paving the way for firms like Sinaco to both expand and diversify their presence in Brazil beyond extraction-related infrastructure.

However, not all greenfield investments imply a cautious or gradual approach. At the other end of the spectrum, a number of Chinese soes have invested directly in mining activities in Peru-LAC's top producer of several minerals, including gold, lead, silver, tellurium, tin and zinc, as well as the region's second-largest regional producer of copper. Peru has a relatively open

2 Interview with an environmental engineer, Rio de Janeiro, November 2015. 
foreign investment regime and is therefore host to a number of foreign mining companies, including from several member countries of the Organization for Economic Co-operation and Development (OECD). In one high-profile case, Chinalco (the Aluminum Corporation of China) became the operator of the largest copper and molybdenum plants in the world, the USD 3.4 billion Toromocho mine, located in central Peru (Jamasmie, 2014). In 2014, just months into operations and before the mine had reached full production, Chinalco had to suspend part of its activities after inspections were carried out. Peru's recently created public environmental watchdog, the Agency for Environmental Assessment and Enforcement (Organismo de Evaluación y Fiscalización Ambiental, OEFA) had expressed concerns over the company's environmental practices, especially the dumping of waste in nearby lakes (OEFA, 2014). Chinalco relocated and resettled a community that had been affected by its mining activities, but the operation has nonetheless been the target of strikes and union disputes.

Also in Peru, Minmetals, which is controlled by China Minmetals, has encountered a different yet equally forceful form of opposition to its major greenfield investments. The company leads a consortium implementing a construction megaproject in Las Bambas, a copper mine in Peru's central highlands. The site employs some 16,000 workers and began producing in late 2015, becoming one of the world's largest copper mines. To help avoid controversy, the Australian-Chinese company MMG, whose majority owner is China Minmetals, agreed to honour a previously established commitment to provide at least one job per family within the local community. However, the mining project has faced repeated environmental protests, including one on September 30, 2015 that left four dead and fifteen injured (Peruvian Times, 2016). In August 2016, residents of several Andean communities blocked a key road to the mine, arguing that it passes through their lands and that the company should pay them for using it; the blockade forced Minmetals to use alternative roads (Reuters, 2016). In the case of Las Bambas, both the greenfield site itself and its related infrastructure have become focal points for community activism, with growing visibility in both Peruvian and overseas media.

Even in these instances of direct engagement in greenfield mining investments, there is a degree of institutional learning, either by individual firms or through collaboration with local actors. Some Chinese firms have actively sought assistance in complying with local standards. For instance, after the Chinalco controversy, the Association of Chinese Companies in Peru requested help from the Peruvian Ministry of the Environment with training on local environmental regulations (Sanborn and Chonn, 2015). However, the degree of institutional learning and the scope and effectiveness of related initiatives also 
depends on the reaction of government institutions and civil society entities. In the case of Peru, prior mobilisation by local organisations had led to the creation and institutionalisation of OEFA, which has worked to ensure that government oversight is accompanied by civil society monitoring of greenfield investments in natural resource extraction. Although this arrangement has not precluded legal disputes-in 2015, four mining companies fined by the agency proceeded to file claims against OEFA in an attempt to have their fines quashed - these disputes so far have not included Chinese firms operating in the country (SPDA, 2015).

\subsection{Mergers and Acquisitions: Entering Ongoing Projects}

In comparison to greenfield projects, mergers and acquisition initiatives do not necessarily require firms to commit significant resources beyond capital. Mergers and acquisitions may also be a way for Chinese companies to participate in 'fringe' or 'frontier' initiatives, in which Chinese firms are willing to assume project roles that bring relatively high short-term financial risks if they entail the long-term potential of returns (Kotschwar et al., 2012). Mergers and acquisitions are often favoured as a way of entering ongoing projects rather than starting new ones from scratch. Yet, as with other modes of investment, the choice of acquiring pre-existing companies in LAC is also shaped by the particular regulations and dynamics of each country.

In Brazil, the existence of relatively high barriers to entry has made mergers and acquisitions more common in the extractive sector than in any other LAC country, in large part because in Brazil mining and oil feature particularly heavy state involvement. In addition, recent legal changes have reinforced this trend. Although the sector had undergone some liberalisation in the late 1990s and into the early years of the twenty-first century, in 2010, after the pre-salt discoveries had been announced, new legislation was introduced setting rules for offshore block auctions (Brazil, 2010). In practice, these legal changes expanded government control of the oil sector, in both production and revenue sharing, short of establishing national monopolies. These changes imposed new constraints on foreign firms entering the sector, leading Chinese companies to opt for mergers and acquisition strategies as a way of participating in the bidding process.

In order to enter the Brazilian oil sector, Sinopec acquired a minority (40 per cent) stake in Repsol in 2010 at a cost of USD 71 billion. The acquisition seems to have an explorative dimension: it allowed Sinopec to acquaint itself with the Brazilian context and to gradually enter other parts of the extractive chain. The company was among the first to try to invest in oil refining in Brazil after the sector was opened, through an attempt to negotiate a deal with the 
country's only private oil refinery, Refinaria Manguinhos in Rio de Janeiro. However, the Manguinhos firm was expropriated by the state government in 2012, leading to the suspension of talks. The refinery resumed production only in 2014, without Chinese participation - an illustration of how, even in the absence of contentious public debates about foreign investments in extraction, volatile local conditions can undermine Chinese companies' M\&A strategies.

In late 2013, Sinopec (as part of a consortium that also includes Norway's Statoil and Brazil's Petrobras) was given the go-ahead from the Brazilian Institute of Environment and Renewable Natural Resources (Instituto Brasileiro do Meio Ambiente e dos Recursos Naturais Renováveis-IBAMA) to explore oil in the pre-salt layer of the BM-C-33 block of the Campos Basin, Brazil's largest known oil field (currently the source of approximately 80 per cent of Brazil's oil production). The IBAMA permit is valid until 2017 and gives the company the right to explore for oil as long as certain environmental conditions are met, including prohibitions on burning residues in the open air and perforating in environmentally sensitive areas. The permit also requires the company to submit an environmental report no later than 60 days after the start of maritime perforation (Menezes, 2013). Yet the robustness of these safeguards has not gone uncontested: local and international environmental groups have drawn attention to the potential environmental risks of drilling for oil and gas in deep layers of the seabed ${ }^{3}$ (Greenpeace, 2012). Thus, in entering the pre-salt business, Sinopec became part of a more direct environmental debate, albeit one that has been subdued in part by the delays in pre-salt exploration caused by falling oil prices and domestic turmoil in Brazil.

In 2015, Chinese companies expanded their M\&A strategies in Brazil, once again in the infrastructure sector. The move shows that M\&A, far from 'providing cover for' Chinese companies, can sometimes place them at the heart of debates about what direction, in terms of development, the country as a whole should take. The government of Dilma Rousseff, mired in deep political crisis and facing an economic recession, held the largest auction of public assets in 17 years, primarily in key infrastructure areas such as transportation and hydroelectric plants. Chinese companies scooped up assets worth billions of dollars, with some economic nationalists decrying the manoeuvre as part of a broad and undesirable privatisation scheme that, in addition to setting back development, would hurt national sovereignty (Hermes, 2015). Dependency was invoked as part of the argument for curtailing the role of Chinese companies in the country's extractive sector and, more broadly, as a way of defending greater national control over pre-salt reserve exploration.

3 Greenpeace, for instance, has drawn attention to the potential risks of a pre-salt oil spill and contamination of fragile ecosystems along the Brazilian coast and in the South Atlantic. 


\subsection{Joint Ventures and the (Vague) Promise of Technology Transfer}

Like greenfield projects and M\&As, the dynamics of Chinese joint ventures in LAC extractive industries depend heavily on the national regulations around such initiatives. When such projects are announced, they tend to be promoted using discourses that stress the role of technology transfer, and indeed, in some places, joint ventures between Chinese and LAC companies in different energy markets have been shown to lead to the transfer of certain important technologies (Husar and Best, 2013), although such transfers vary in scope and level of innovation.

The joint-venture strategy seems to be particularly common in the oil sector, in part because of local requirements (especially in countries where there is a strong push to maintain 'national' majority control of exploration) and the scale of resources needed to explore for, produce and refine crude oil. In Venezuela, where foreign oil firms by law can only have a maximum stake of 40 per cent in joint ventures, the bulk of Chinese investments in the extractive industries are structured through joint ventures; in fact, a fund has been set up by the Venezuelan government specifically for joint oil investments. China's largest oil and gas producer and supplier, the China National Petroleum Corporation (CNPC), has an arrangement with Venezuela's national oil company, PDVSA, in which Venezuela's loans from China are repaid in oil-a situation unique in LAC. And the recent decline in oil prices has further indebted Venezuela to China, with PDVSA announcing that it will increasingly rely on joint ventures - including with CNPC - to manage USD 6 billion in loans designed to reverse oil output declines (Crooks and Pons, 2013). While China has continued to bolster the Venezuelan economy, announcing USD 20 billion of new investments in 2015 to help offset the effects of plunging oil prices, the country's growing instability has led some analysts to interpret the move as a sign that China is treating the country as an experiment in political risk analysis within the region (Ferchen, 2013).

Yet Chinese joint ventures in LAC have not been limited to the oil sector. In 2012, subsidiaries of the China Railway Construction Corporation (CRCC) and Tongguan Nonferrous Metals Group Holding Company paid USD 100 million to the Ecuadorean government for the rights to the Mirador Copper Mine, committing to invest USD 1.4 bn over the next five years. This large-scale mining project in the Amazon has been heavily criticised by civil society groups who allege that the investment violates China's Green Credit Directive, a government policy requiring banks to take into account the social and environmental impacts of projects and to conform to 'international norms' and 'good international practices' in overseas lending (Hill, 2015). In Chile, China Minmetals Nonferrous Metals Co. set up a joint venture with the Corporación Nacional del Cobre de Chile (CODELCO), the world's largest producer of copper, to secure 
supplies of the metal and to carry out joint exploration and develop projects together. Negotiations for these initiatives are typically launched under a discourse of win-win relationships, with vague promises of technology transfer stressed by all parties. Negotiators also tend to underscore the possibility of accessing funding from Chinese state-affiliated banks, such as the China Development Bank ( $\mathrm{CDB})$, for large-scale projects.

However, even $5^{0-50}$ joint ventures are not devoid of asymmetries benefiting China. In the Ecuadorean case, for instance, there are steep interest payments, along with the requirement that Ecuador use mostly Chinese companies and technologies on related projects (Krauss and Bradsher, 2015). Although such clauses are far from the kind of political and cross-sectoral conditionalities that are sometimes imposed by Northern donors and established international organisations like the IMF, their inclusion in joint-venture contracts indicates that, despite the official discourse of win-win relationships, Chinese investments are also marked by power asymmetries that may become steeper over time if LAC economies encounter economic hurdles such as those currently generated by the drop in oil prices.

As with other modalities of investment, most Chinese announcements of major joint ventures in LAC have not come to fruition. A planned USD 5 billion steel mill joint venture between Wuhan Iron and Steel Company (WISCO) and the Brazilian company MMX, a USD 1.4 billion Baosteel-CVRD joint venture steel mill in the north-eastern state of Maranhão, and a joint venture between Baosteel and Brazil's Gerdau, discussed in 2006, are examples of major initiatives that were announced yet have not been implemented (Ellis, 2014, 15). Likewise, in 2009, the China National Offshore Oil Corporation (CNOOC) announced a USD 3.1 billion investment in a joint venture with the Argentine oil and gas holding company Bridas, meant to increase reserves of crude oil (CNOOC Ltd., 2010), but by 2014 the Chinese state-owned company was seeking to sell its stake to free up money for other projects. Whether due to regulatory issues, changing investment contexts, or political resistance, a large number of proposed joint ventures have either gone unimplemented or have led to frustrated expectations, including with respect to technology transfer.

\section{New Sources of Uncertainty, Upstream and Downstream}

Just as Chinese investments in LAC extractive industries vary considerably in shape and size, encompassing everything from opencast mining megaprojects and major mergers and acquisitions to modest joint ventures, so have they varied over time. Over the past two years, both China and LAC have been 
experiencing some dramatic changes. The Chinese economy has been undergoing a relative slowdown, with GDP growth at around 7 per cent in 2015, even as the leadership works to transform the economy from a model that is driven primarily by infrastructure investment and manufacturing towards one in which domestic consumption and the services sector play a bigger role. More broadly, some Chinese companies have responded to steep drops in many commodity prices, including that of iron ore, by being choosier about their investments abroad, especially by being more conservative in their risk calculations. In turn, some partner countries have also become more wary about Chinese investments as the behaviour of companies adapts to new sources of uncertainty and as major announcements fail to come to fruition (Ricciardi, 2015).

In addition, Beijing's pursuit of new geopolitical alignments, as well as its emerging or re-emerging tensions with neighbouring states, especially within the South China Sea, have implications for Chinese investments in LAC. Territorial claims that are disputed by Japan and other Pacific states are particularly prone to lead to escalating tensions, and these tensions have exacerbated rivalries between China and the United States. At the same time, the Chinese government is planning a broad scheme, the One Belt, One Road (овоR) initiative, that is designed to extend China's reach and influence across a broad swatch stretching from East Asia to Europe. These concerns and interests mean that Chinese investments in LAC, although underpinned by a long-term interest in securing reliable access to natural resources, exist within a geographical region that is at best secondary among Chinese foreign policy and defence priorities, although the BRICS New Development Bank has announced that one of its first loans will be allocated to Brazil (the other three are in China, South Africa, and India) (NDB, 2016).

At the same time, there are also significant changes afoot in LAC that have implications for incoming FDI from China. Several of the region's economies have been experiencing deceleration; LAC's GDP growth slowdown deepened and was expected to be negative in 2015, for the second consecutive year falling behind the average growth of OECD countries after one decade of convergence with advanced economies (OECD/CAF/ECLAC 2015). The region's largest economy, Brazil, officially entered recession mode amidst political turmoil, including a presidential impeachment process and a far-reaching anti-corruption drive that affects not only major companies but also major political parties and government institutions. This scenario generates deep uncertainty for foreign investors, including those in the extractive sector. Plans for the extraction of pre-salt oil off the Brazilian coast, once heralded as the beacon of a new development era for Brazil, have been affected not only by 
the crisis, but also by price drops in oil and gas, creating new pressures to open up exploration of the reserves to foreign investors (Garcia, 2016). While some local stakeholders look to China as a source of emergency funding, especially through trade and investments in energy and infrastructure (Schreiber, 2015), the challenging scenario in Brazil (added to the turbulence in Venezuela) has also made Chinese investors more cautious towards LAC economies (Valor Econômico, 2015).

Elsewhere in LAC, the political winds of change have also cast doubt over the policies being implemented in the countries that some of the largest recipients of Chinese investments. In November 2015, for instance, the Peronist-inspired government of Cristina Fernández de Kirchner gave way to the government of Mauricio Macri, who has stressed a break with the policies of the previous Argentine administration. In Venezuela, the socialist-inspired government of Nicolás Maduro, successor to Hugo Chávez, suffered a major defeat in the 2015 congressional elections, with the opposition claiming a legislative majority that is set to considerably modify the political balance in Venezuela. These changes sometimes have a direct effect on China's role in the extractive sector in the region. Instability in Venezuela, whose top oil customer (and investor) is China, prompted Caracas to renegotiate its oil-for-loans deal ahead of heavy debt payments (Ulmer and Pons, 2016). Combined with the uncertainty stemming from China's economic deceleration, these shifts have created greater caution on the part of Chinese investors, as well as a willingness to redirect flows within the region and beyond it.

\section{Conclusion}

Research on Chinese economic cooperation with Latin American partners has noted a sharp increase in announcements of major investments in LAC, but new attention must be paid to how this capital enters Latin American markets, and to how stakeholders respond to fast-changing circumstances. The adoption of multiple strategies by Chinese companies, and their increasing bets on mergers and acquisitions rather than greenfield projects or joint ventures, suggest a degree of institutional learning on the part of Chinese companies and their financing institutions, and hint at a more cautious stance being adopted in light of the growing instability and uncertainty in key Latin American partner states.

The choice to invest through a particular modality is shaped not only by local regulations and the associated costs and advantages, but also by the perception that certain types of investment may generate political debates that 
Chinese stakeholders would rather avoid. As cases in Peru, Chile and Ecuador have shown, greenfield projects can become particularly contentious when operations are perceived by local actors to have negative environmental, social and economic consequences. Such debates sometimes entail charges of Chinese neo-colonialism, imposed dependency, and lax adherence to formal regulations-accusations that Chinese companies (often having accumulated considerable experience in Africa before entering Latin American markets) work to avoid in planning a long-term strategy in LAC. This helps to explain the growing salience of mergers and acquisitions. A large greenfield project involving opencast mining or oil extraction in an environmentally sensitive area is more likely to generate debate (and, therefore, a political backlash) than is an acquisition in which a Chinese company becomes part of a larger entity, and in which the Chinese presence is rendered more discreet through its 'dilution' by broader corporate associations.

The political risks that major greenfield investments can generate for Chinese actors may help to explain why, in some contexts, Chinese mining firms enter the market more indirectly, in particular by building infrastructure designed to facilitate extractive activities, especially in storage and transportation. Chinese companies may use this type of low-key entry into LAC markets as a way of learning about the country's conditions, institutions and regulatory frameworks - in general, assessing economic and political risks — rather than 'diving headlong' into prospection and extraction. In sum, they work to skirt rather than court political controversy over investments in natural resource extraction.

Although joint ventures make up a small minority of such investments and appear mostly where local regulations dictate majority ownership by national actors, this modality of investment has become especially salient in the discourse of South-South cooperation between China and LAC because it suggests equal or complementary participation by Chinese and local counterparts, and because (in theory, at least) such arrangements facilitate information sharing and technology transfer. In practice, however, and despite lacking political conditionalities, joint ventures tend to come with many Chinese strings attached, such as requirements about the use of Chinese firms and personnel, which creates new power asymmetries.

Further research on Chinese investments in LAC's extractive industries should seek to shed light on at least two themes explored in this chapter. First, the megaprojects that have been announced during the past five years should be studied more closely, particularly those that are implemented, and with special attention to potential impacts on local socio-economic, political and environmental dynamics. In addition, there is a need for a more fine-grained 
examination of how different local non-state actors, such as NGOs and unions, perceive and engage with these different modalities of investment. Finally, future research should closely monitor any LAC investments financed through the BRICS New Development Bank and other new multilateral development initiatives in which China plays a role of dominant or shared leadership.

\section{References}

Aizenman, J. (2015) 'What's the future of China's overseas investment?' World Economic Forum, http://www.weforum.org/agenda/2015/05/whats-the-future-of-chinas-over seas-investment/ (accessed on 15 July 2016).

Alden, C. and M. Davies (2006) 'A Profile of the Operations of Chinese multinationals in Africa', South African Journal of International Affairs, 13(1), pp. 83-96, DOI: 10.1080/10220460609556787.

Brazil, Presidency of the Republic (2010) 'Law Number 12351' (Brasilia: Presidência da República) 22 December, http://www.planalto.gov.br/ccivil_03/_Ato2007-2010/2010/ Lei/L12351.htm (accessed on 15 July 2016).

Carcovic, M. and R. Levine (2002) 'Does Foreign Direct Investment Accelerate Economic Growth?' in H.T. Moran, E. Graham and M. Blomstrom (eds.) Does FDI Promote Development? (Washington, D.C.: Institute for International Economics).

Cardoso, F.H. and E. Faletto (1979) Dependência e Desenvolvimento na América Latina: Ensaio de Interpretação Sociológica (Rio de janeiro: Editora LTC).

China, Ministry of Foreign Affairs of the People's Republic of (2015), 'First Ministerial Meeting of China-CELAC Forum Grandly Opens in Beijing' (Beijing: Ministry of Foreign Affairs) 1 January, http://www.fmprc.gov.cn/mfa_eng/zxxx_662805/ t1227318.shtml (accessed on 15 July 2016).

CNOOC Ltd. (2010) 'CNOOC Ltd. Established Joint Venture with Bridas Energy Holdings', presentation March 14 (Hong Kong: CNOOC), http://www.cnoocltd.com/up load/encnoocltd/tzzgx/yjhtjcl/Presentations/images/2010314651.pdf (accessed on 15 July 2016).

Crooks, N. and C. Pons (2013) 'Venezuela Said to Allow Oil Joint Ventures to Manage Fund', Bloomberg, 17 May, http://www.bloomberg.com/news/articles/2013-05-17/ venezuela-said-to-allow-oil-joint-ventures-to-manage-fund (accessed on 13 January 2017).

Dunning, T. (2008) Crude Democracy: Natural Resource Wealth and Political Regimes (New York: Cambridge University Press).

ECLAC (Economic Commission for Latin America and the Caribbean) (2015) 'Foreign Direct Investment in Latin America and the Caribbean' (Santiago, Chile: CEPAL), 
LC/G.2641-P, http://repositorio.cepal.org/bitstream/handle/11362/38215/S1500534 _en.pdf (accessed on 15 July 2016).

Ellis, R. (2014) China on the Ground in Latin America: Challenges for the Chinese and Impacts on the Ground (New York: Palgrave Macmillan).

Ellis, R. (2009) China in Latin America: The Whats \& Wherefores (Boulder: Rienner).

Ferchen, M. (2013) 'Political Risk Analysis with Chinese Characteristics', presentation at China's Outbound Direct Investments: Risks and Remedies, September 23-24 (Beijing: Tsinghua University).

Frischtak, C., A. Soares and T. O'Conor (2013) 'Chinese Investments in Brazil from 2007-2012: A review of recent trends', June 2013 (Rio de Janeiro: China-Brazil Business Council), http://www.cebc.org.br/sites/default/files/pesquisa_investimentos _chineses_2007-2012_-_ingles_1.pdf (accessed on 23 March 2017).

Furtado, C. (1974) O mito do desenvolvimento econômico (Rio de Janeiro: Paz e Terra).

Gallagher, K. and R. Porzecanski (2010) The Dragon in the Room: China \& the Future of Latin American Industrialization (Palo Alto: Stanford University Press).

Garcia, G. (2016) 'Crise na Petrobras “obriga” mudança em exploração do pré-sal, diz Renan', O Globo, 16 February, http://g1.globo.com/politica/noticia/2016/o2/crise-na -petrobras-obriga-mudanca-em-exploracao-do-pre-sal-diz-renan.html (accessed on 15 July 2016).

Germani, G. (1969) 'Stages of Modernization in Latin America', Studies in Comparative International Development 5(8), pp. 155-174, DOI: 10.1007/BFo2800615.

Gonzalez-Vicente, R. (2011) 'China's engagement in South America and Africa's extractive sectors: new perspectives for resource curse theories', The Pacific Review 24(1), pp. 65-87, DOI: 10.1080/09512748.2010.546874.

Greenpeace (2012) 'O conflito entre pré-sal e meio ambiente' (São Paulo: Greenpeace), http://www.greenpeace.org/brasil/pt/Multimidia/Videos/O-conflito-entre-pre-sale-meio-ambiente/ (accessed on 15 July 2016).

Hermes, F. (2015) 'Ontem rolou o maior leilão de privatização em 17 anos—os chineses levaram e você nem ficou sabendo', Spotniks, 26 November, http://spotniks.com/ ontem-rolou-o-maior-leilao-de-privatizacao-em-17-anos-os-chineses-levaram-e -voce-nem-ficou-sabendo/ (accessed on 15 July 2016).

Hill, D. (2015) 'Chinese banks ignore pleas of Ecuador mining campaigners', China Dialogue 5 December, https://www.chinadialogue.net/article/show/single/en/6966 -Chinese-banks-ignore-pleas-of-Ecuador-mining-campaigners (accessed on 15 July 2016).

Huang, X. and Y. Zhu (2016) Managing Chinese Outward Foreign Direct Investment: From Entry Strategy to Sustainable Development in Australia (New York: Springer).

Husar, J. and D. Best (2013) Energy Investments and Technology Transfer Across Emerging Economies: The Case of Brazil and China, Partner Country Series (Paris: International 
Energy Association), https://www.iea.org/publications/freepublications/publication/PCS_ChinaBrazil_FINAL_WEB.pdf (accessed on 15 July 2016).

Irwin, A. and K. Gallagher (2013) 'Chinese Mining in Latin America: A Comparative Perspective', The Journal of Environment Development 22(2), pp. 207-234, DOI: 10.1177/1070496513489983.

Jamasmie, C. (2014) 'Chinalco forced to halt Peru's copper project over ongoing pollution', mining.com, http://www.mining.com/chinalco-forced-to-halt-perus-copper -project-over-ongoing-pollution-28717/ (accessed on 15 July 2016).

Jenkins, R. (2015) 'Is Chinese Competition Causing Deindustrialization in Brazil?' Latin American Perspectives 42(4), pp. 42-63, DOI: 10.1177/0094582X15593553.

Kotschwar, B., T. Moran and J. Muir (2012) China's Investment in Latin American Resources: the Good, the Bad, and the Ugly, Working Paper Series 12-3 (Washington, D.C.: Peterson Institute for International Economics), http://www.iie.com/publica tions/wp/wp12-3.pdf (accessed on 15 July 2016).

Krauss, C. and K. Bradsher (2015) 'China's Global Ambitions, Cash and Strings Attached', New York Times, 24 July, http://www.nytimes.com/2015/07/26/business/ international/chinas-global-ambitions-with-loans-and-strings-attached.html?_r=o (accessed on 15July 2016).

Li, D. (2009) 'Innovation and Knowledge Transfer in Chinese Multinationals', in J.-P. Larçon (ed.) Chinese Multinationals (London: World Scientific), pp. 151-166.

Lichtenstein, J. (2013) 'How does China drive the mining and metals business?' Yale Insights 26 June, http://insights.som.yale.edu/insights/how-does-china-drive-min ing-and-metals-business (accessed on 15 July 2016).

Menezes, B. (2013) 'Pré-Sal: Chineses avançam sobre a Bacia de Campos', Epoch Times, 11 November, https://www.epochtimes.com.br/pre-sal-chineses-avancam-baciacampos/\#.V7ctxmUSFcB (accessed on 15 July 2016).

Moran, T. (2010) China's Strategy to Secure Natural Resources: Risks, Dangers, and Opportunities, Policy Analysis in International Economic, 92 (Washington: Peterson Institute for International Economics).

NDB (New Development Bank) (2016) BRICS Bank gives $\$ 811$ million in first round green energy loans (Shanghai: New Development Bank), http://www.ndb.int/brics-bankgives-811-million-in-first-round-green-energy-loans.php (accessed on 15 July 2016).

OECD (Organisation for Economic Cooperation and Development) (2015) Strengthening Chile's investment promotion strategy (Paris: OECD Publishing), https://www .oecd.org/daf/inv/investment-policy/Chile-investment-promotion-strategy-2015 .pdf (accessed on 15 July 2016).

OECD, CAF (Banco de Desarrollo de América Latina) and ECLAC (Economic Commission for Latin America and the Caribbean) (2015), Latin American Economic Outlook 2016: Towards a New Partnership with China (Paris: OECD Publishing), DOI: 10.1787/9789264246218-en. 
OEFA (Organismo de evaluacion y fiscalizacion ambiental) (2014) 'OEFA ordena a Minera Chinalco Perú detener actividades causantes de vertimientos en lagunas de Junín' [Video] Arch 28 (Lima: OEFA), https://www.youtube.com/watch?v=7QpOdx TO2Qo\&feature=player_embedded (accessed on 15 July 2016).

Peruvian Times (2016) 'Las Bambas Protests Leave Four Dead, 15 Injured, Peruvian Times, 19 August, http://www.peruviantimes.com/30/las-bambas-protests-leavefour-dead-15-injured/24918/ (accessed on 15 July 2016).

Prebisch, R. (1950) The Economic Development of Latin America and Its Principal Problems (New York: United Nations).

Raff, H., M. Ryan and F. Stahler (2004) Mergers vs Joint Ventures vs Greenfield Investment: A Comprehensive Treatment of Foreign Direct Investment (mimeo, preliminary version), https://editorialexpress.com/cgi-bin/conference/download.cgi?db_ name=mwie2005\&paper_id=18 (accessed on 15July 2016).

Ray, R. and K. Gallagher (2015) China-Latin America Economic Bulletin 2015 Edition, Discussion Paper 2015-9 (Boston: Boston University), https://www.bu.edu/pardeeschool/files/2015/02/Economic-Bulletin-2015.pdf (accessed on 15 July 2016).

Reuters (2016) 'Protesters in Peru block key road to Las Bambas copper mine', Reuters, 15 August, http://www.reuters.com/article/us-peru-copper-mmg-ltd-idUSKCN1oQ1ZJ (accessed on 15 July 2016).

Ricciardi, A. (2015) 'Será que os bilionários investimentos chineses chegarão ao Brasil?' Forbes Brasil, August 15, http://www.forbes.com.br/negocios/2015/o8/sera-que -os-bilionarios-investimentos-chineses-chegarao-ao-brasil/ (accessed on 12 January 2017).

Sachs, J. (2014) The Age of Sustainable Development (New York: Columbia University Press).

Salazar, R. (2015) 'Chinese Investment in Latin America: A Poisoned Chalice?' Huffington Post, http://www.huffingtonpost.com/rafael-salazar/chinese-investment-in -lat_b_762116o.html (accessed on 15 July 2016).

Sanborn, C. and V. Chonn (2015) Chinese Investment in Peru's Mining Industry: Blessing or Curse?, Economic Governance Initiative Discussion Paper 2015-8 (Boston: Boston University), http://www.bu.edu/pardeeschool/files/2014/12/Peru2.pdf (accessed on 13 January 2017).

Santos, T. (1970) 'The Structure of Dependence', The American Economic Review 6o(2), pp. 231-236, http://www.jstor.org/stable/1815811.

Schreiber, M. (2015) 'Lava Jato abre espaço para investimento chines no Brasil', $B B C$ Brasil, http://www.bbc.com/portuguese/noticias/2015/05/150512_china_lavajato _mariana_ru (accessed on 15 July 2016).

SPDA (Sociedad Peruana de Derecho Ambiental) (2015) 'Cuatro mineras que quieren debilitar al OEFA tienen multas por más de 10,4 millones de soles', Actualidad Ambiental, http://www.actualidadambiental.pe/?p=28964 (accessed on 15 July 2016). 
Te Velde, D. (2006) Foreign Direct Investment and Development: An historical perspective, Overseas Development Institute Background paper (London: ODI), https:// www.odi.org/sites/odi.org.uk/files/odi-assets/publications-opinion-files/850.pdf (accessed on 12 January 2017).

The Economist (2015) 'The Chinese chequebook', 23 May, http://www.economist.com/ news/americas/21651889-latin-america-needs-be-more-hard-headed-its-big-new -partner-chinese-chequebook (accessed on 15 July 2016).

Trubek, D., H. Alviar Garcia, D. Coutinho and A. Santos (2014) Law and the Developmental State: The Brazilian Experience in Latin American Context (Cambridge: Cambridge University Press).

Ulmer, A. and C. Pons (2016) 'Venezuela says better oil loans deal reached with China', Reuters, http://www.reuters.com/article/us-venezuela-economy-idUSKCNoY $71 \mathrm{VB}$ (accessed on 15 July 2016).

Valor Econômico (2015) 'China troca de amigos na América Latina e se aproxima do Brasil', 12 November, http://www.investe.sp.gov.br/noticia/china-troca-de-amigos -na-america-latina-e-se-aproxima-do-brasil/ (accessed on 15 July 2016).

World Bank (2016) 'Extractive Industries: Overview’ (Washington, D.C.: World Bank), http://www.worldbank.org/en/topic/extractiveindustries/overview\#3 (accessed on 15 July 2016).

World Bank (2015) 'Extractive industries in Latin America \& Caribbean' (Washington, D.C.: World Bank), http://www.worldbank.org/en/topic/extractiveindustries/x/lac (accessed on 15 July 2016).

World Bank, IFC (International Finance Corporation) and CAF (Banco de Desarrollo de América Latina) (2013) Regulating Foreign Direct Investment in Latin America (Washington, D.C.: World Bank), http://iab.worldbank.org/ /media/FPDKM/IAB/ Documents/Regulating-FDI-in-Latin-America.pdf (accessed on 15 July 2016). 